\title{
The taxonomic entity and distribution of Korean Sedum formosanum (Crassulaceae) revealed in 133 years
}

\author{
Seung Se CHOI, Jonghwan KIM ${ }^{1}$ and Chul Hwan KIM ${ }^{1 *}$ \\ Team of National Ecosystem Survey, National Institute of Ecology, Seocheon 33657, Korea \\ ${ }^{1}$ Sung-ho Green Tech, Jangseong 57248, Korea \\ (Received 19 August 2020; Revised 4 December 2020; Accepted 22 December 2020)
}

\begin{abstract}
Korean Sedum formosanum N. E. Br. (Ju-geog-nip-gaet-bi-reum in Korean) was first recorded in 1887, 133 years ago. Since then, the species has not been collected and its current state has remained unclear. However, these plants were collected in 2020 and the corresponding taxonomic entity and distribution status were revealed. It is known to be distributed only in the southern region of Japan, the northern islands of the Philippines, and in Taiwan, with Taiwan being the collection site of the type specimen. However, on the basis of the findings of the fourth national natural environment survey, it has recently been established that this plant also grows in the crevices of rocks along the seashores of the Korean islands of Hataedo Island and Sangtaedo Island, Sinan-gun, Jeollanam-do. S. formosanum inhabiting Korea is a large succulent biennial that can attain a height of up to $65 \mathrm{~cm}$ and differs from its congeneric species in having erect follicles during the fruiting period. Notably, among the Korean Sedum species, S. formosanum is most similar to S. tosaense, although it can be distinguished from this species with respect to its monomorphic leaves that have rounded apices, and it also bears separate flowering and sterile stems. In this paper, we present a description and photographs of the Korean $S$. formosanum, indicate the differences between this and related species, and provide a key to related taxa.
\end{abstract}

Keywords: taxonomic entity, S. formosanum, Sedum, Crassulaceae, island region

The genus Sedum L. in Korea, which belongs to the Crassulaceae J. St.-Hil., has traditionally been recognized to include the Phedimus Raf. and Hylotelephium H. Ohba (Lee, 1980; Lee, 1996), or has been treated with Phedimus except for Hylotelephium (Park, 2007). However, many authors have recently recognized Phedimus and Hylotelephium as separate genera from the Sedum (Fu and Ohba, 2001; Ohba, 2001; Thiede and Eggli, 2007; Moran, 2009). Sedum sensu stricto is the largest genus in the family, taxonomically including $420 ? 470$ taxa worldwide (Fu and Ohba, 2001; Thiede and Eggli, 2007; Ohba, 2009). Geographically, they are mainly distributed in temperate and subtropical regions of the Northern Hemisphere, and a small number of taxa are known to be distributed to Africa and S America in the Southern Hemisphere (Fu and Ohba, 2001; Thiede and Eggli, 2007).

Sedum s.s can be distinguished from Orostachys Fischer and Meterostachys Nakai by the presence of stems without rosette leaves at least during the flowering period, from Tillaea L. by the presence of twice the stamen number than petals, it is distinguished from Hylotelephium by the presence of yellowish flowers and carpels without stalks, and from Phedimus and Rhodiola L. by the presence of leaves with entire margins and non-thickened roots (Fu and Ohba, 2001; Ohba, 2001). Furthermore, Moon (2018) suggested the height of taxa, stem base habit, and the patterns of seed surface through key to the Korean Sedum and Phedimus as the identifying features of Sedum.

The Korean Sedum s.s. was first reported by Forbes and Hemsley (1887) when they identified three species, $S$. alfredii Hance, S. formosanum N. E. Br. and S. sarmentosum Bunge, based on the specimens of herbarium K 133 years ago, and then Palibin (1898) mentioned two species, S. sarmentosum and $S$. alfredii. Since then, taxonomic studies have been conducted on Korean Sedum (Kim, 1988; Moon, 2018), and

\footnotetext{
*Author for correspondence: plantaxa@hanmail.net
} 
described in the flora manuals written by several authors (Nakai, 1909, 1952; Chung, 1957; Park, 1974; Lee, 1980; Lee, 1996; Lee, 2007; Park, 2007).

So far, a total of 10 taxa of Sedum s.s. are known to occur in Korea, including an endemic species $S$. lepidopodum Nakai (Nakai, 1940), three recently recorded species (S. tosaense Makino, S. makinoi Maxim, and S. kiangnanense D. Q. Wang \& Z. F. Wu) (Song et al., 2004; Park and Park, 2005; Suh et al., 2020), and one introduced species, S. mexicanum Britton (Park, 2009). Moreover, several authors (Maximowicz, 1883; Forbes and Hemsley, 1887; Palibin, 1898; Nakai, 1909, 1952; Lee, 1996) have mentioned that $S$. alfredii is distributed in southern islands or Jejudo Island, but Kim (1988) predicted this as $S$. bulbiferum Makino. Similarly, S. subtile Miq. mentioned by Lee $(1996,2007)$ as being distributed in Jejudo Island, is believed to be a misidentification of $S$. tosaense.

Forbes and Hemsley (1887) pointed out the distribution of S. formosanum in Korea, but Kim (1988) reported that no specimens were observed that could confirm its distribution through taxonomic study of Sedum s.l. Currently, S. formosanum is known to be distributed in Taiwan, southern Japan, and the northern Philippines, but its distribution and taxonomic entities in Korea remain unclear. Moreover, recent studies on S. formosanum abroad have not mentioned Korea as a distribution area.

However, a recent national survey of the natural environment confirmed that $S$. formosanum is distributed on the beachside of Hataedo and Sangtaedo islands, Sinan-gun, Jeollanam-do in Korea. Therefore, the authors report their entity through this article 133 years after the initial publication, providing evidence of the $S$. formosanum distribution in the Korean peninsula.

\section{Taxonomic Treatment}

Sedum formosanum N. E. Br., Gard. Chron. Ser. 24: 134, 1885 (Figs. 1, 2).-TYPE: Taiwan. Kelung, C. Ford s.n. (K, $\mathrm{GH}$, seen only photos!).

Korean name: 주걱잎갯비름 (Ju-geog-nip-gaet-bi-reum).

Herbs, biennial, fleshy, glabrous. Roots fibrous, sometimes adventitious leaf scars. Stems: first year stems stout, erect, only sterile, 1-trifurcate, ca. $10 \mathrm{~cm}$ height, overwintering, reddish brown later; second year stems erect, decumbent at bases, 12(-3)-trifurcate, $20.0-45.0(-65.0) \mathrm{cm}$ height, up to $1 \mathrm{~cm}$ wide at bases, reddish brown and yellowish brown later, flowering all, sprawling after flowering period. Petioles sessile or nearly so. Leaves: first year leaves alternate with lax rosettes, spreading, green, spatulate to widely obovate; second year leaves alternate, green or yellowish green later, flattish, thick, spatulate to widely obovate, $0.8-4.8 \times 0.5-1.5 \mathrm{~cm}$, bases long attenuate, margins entire, apices rounded. Inflorescences terminal, cymes, 1-2-trifurcate with $3(-4)$ primary axes; primary axes $2.0-15.0 \mathrm{~cm}$ long, ascending, 1 to several times irregularly and often unequally forking, with a flower at each fork; bracts leaflike, smaller than cauline leaves. Flowers 5(6)-merous, 1.0-13.0 mm wide, sessile. Sepals 5, free, green or yellowish green later, fleshy, flattish, unequal in size, obovate to oblanceolate, 3.0-7.0 $\times 1.5-3.0 \mathrm{~mm}$, apices rounded. Petals $5(-6)$, bright yellow, lanceolate, 5.0-6.0 × 1.3-1.6 mm, bases slightly connate, apices short acuminate. Stamens 10(-12), slightly shorter than petals, ascending at flowering, 2-whorled; anthers oblong-lanceolate, ca. $0.5 \mathrm{~mm}$ long, deep yellow. Carpels 5 , ca. $5 \mathrm{~mm}$ long, free, connate at the bases, gibbous ventrally. Fruits follicles, star-shaped, erect, ca. $7 \mathrm{~mm}$ long. Seeds elliptical, $0.4-0.6 \times$ ca $0.1 \mathrm{~mm}$.

Flowering: June to early August.

Habitat: Approximately 50 individuals were found growing along with Lysimachia mauritiana Lam. [Primulaceae Batsch ex Borkh.] in open and dried stone crevices within a $70 \times 7$ $\mathrm{m}$ area of a Pinus thunbergii Parl. and Euonymus japonicus Thunb. plant community, located adjacent to the island's coast. Given that the native habitat of plants lies along the side of the coastal road, the population is considered to be highly susceptible to disturbance, by both road maintenance projects and the disposal or stacking of fishing gear in the vicinity of habitat, thereby threatening the viability and survival of $S$. formosanum on Hataedo Island.

Distribution: Japan (South), Korea (Jeollanam-do), Philippines (North), Taiwan.

Specimens examined: KOREA. Jeollanam-do: Sinan-gun, Hataedo Island, 3 Aug 2020, C. H. Kim \& S. S. Choi 20001 (19 sheets, JNU).

Sedum formosanum was described as a new species by Brown (1885) based on the type specimens collected by Ford from Keelung, northeast Taiwan, and recently, $S$. danjoense Takuro Ito, H., Nakan. \& Kokub and S. formosanum subsp. miyakojimense Takuro Ito, Yokota \& Kokub. which are similar to $S$. formosanum, were also described as new taxa (Ito et al., 2017, 2020). Notably, Ito et al. (2017) used life cycle, stem branching pattern, number of carpels, the shape of sepals and follicles, and habitat as major diagnostic characters to differentiate similar taxa, including $S$. formosanum.

The Korean $S$. formosanum was recorded earlier by Forbes and Hemsley (1887) as growing on the southern island, based on the Oldham's specimen (266). Since then, Kim (1988) has 


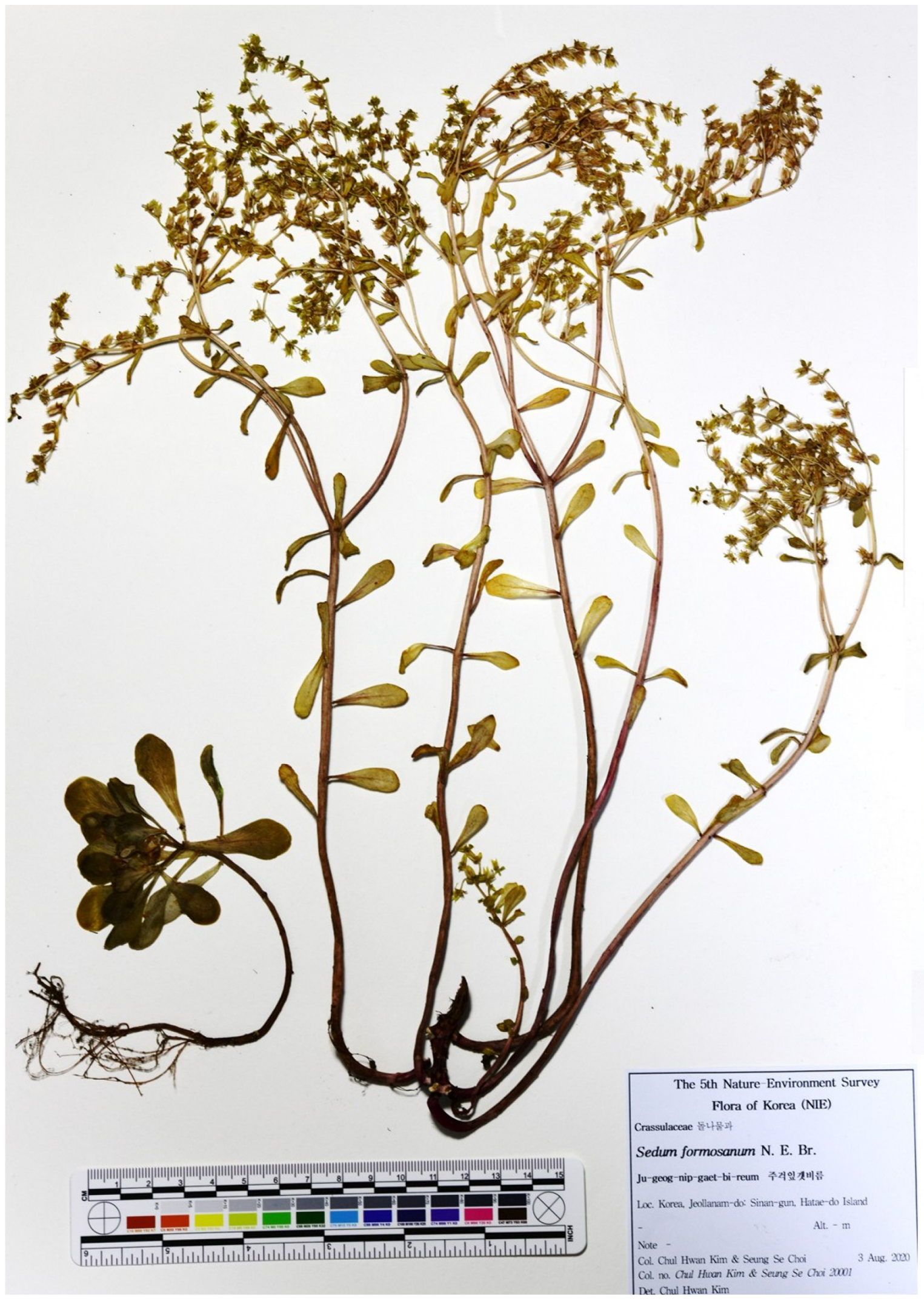

Fig. 1. Voucher specimen of Sedum formosanum collected from Hataedo Island by the authors. Lower left side of specimen is the sterile stem of the first year, while right side shows the branching fertile stem of the second year. 

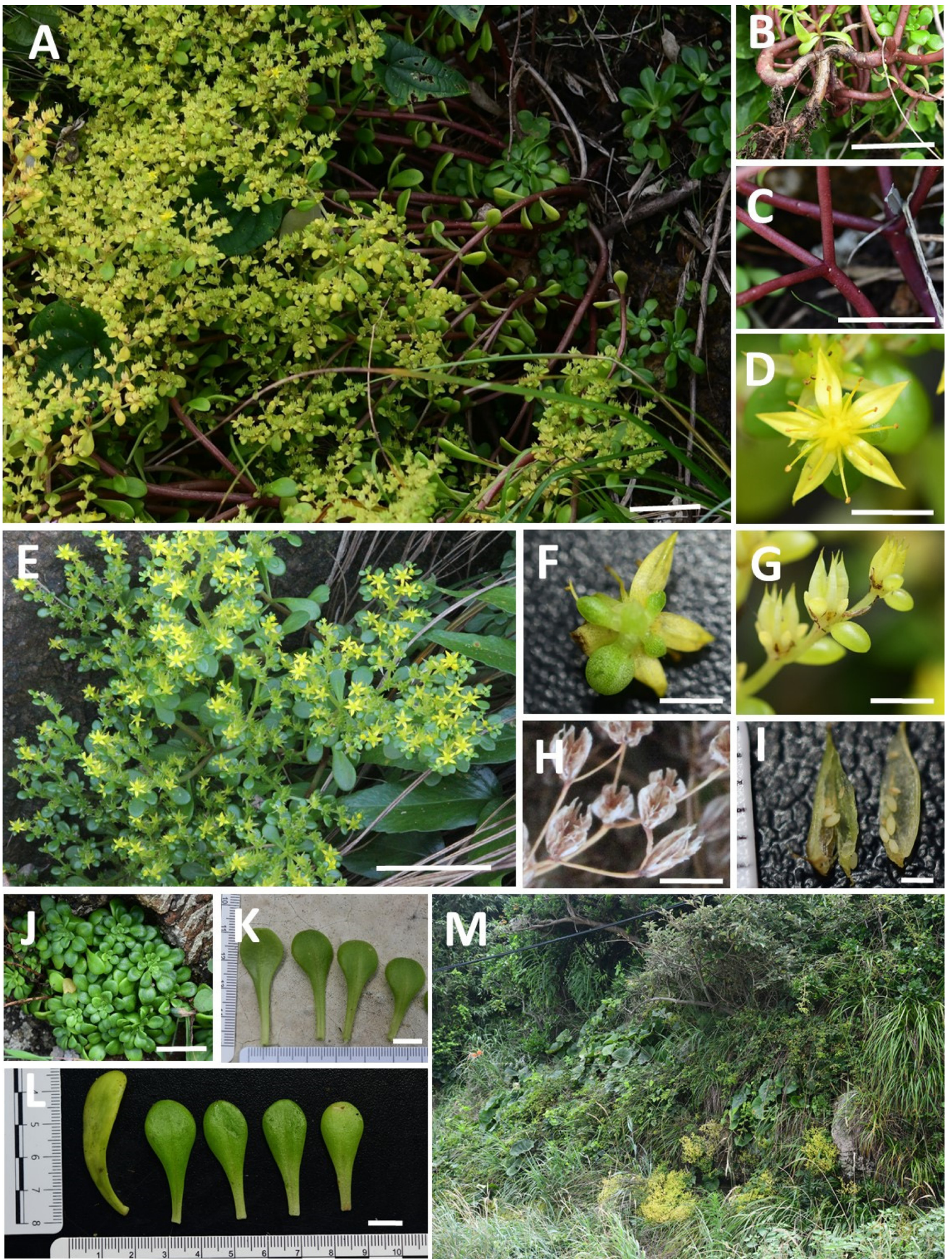

Fig. 2. Sedum formosanum. A. Flowering plant with reddish brown stem and yellowish inflorescence. B, C. Stems with trifurcate patterns at base (B) and above middle (C). D. Flower with 5-petals and 10-stamens. E. Cymose inflorescence in flowering stem. F. Sepals with unequal in size. G, H. Carpels in younger fruit stage $(\mathbf{G})$ and adult stage $(\mathbf{H})$. I. Seed in very early maturing stage. J. Sterile stem of first year. K, L. Leaf blades on sterile stems (K) and flowering stems (L). M. Habitat around beach. Scale bars $=5 \mathrm{~cm}(\mathrm{~A}-\mathrm{C}, \mathrm{E}, \mathrm{J}), 1 \mathrm{~cm}(\mathrm{~K}, \mathrm{~L}), 5 \mathrm{~mm}(\mathrm{D}, \mathrm{F}-$ H), $1 \mathrm{~mm}$ (I) (photos by S. S. Choi and C. H. Kim). 
reserved her decision on the taxonomic entity of Korean $S$. formosanum because she did not observe the Oldham's specimen during her monographic study of the Korean genus Sedum, but again, no author has mentioned its presence and distribution to date. Meanwhile, Maximowicz (1883) reported that $S$. alfredii was distributed in Korea based on C. Wilford's specimen, and then, Forbes and Hemsley (1887), Palibin (1898), Nakai (1909, 1952), and Lee (1996) also agreed with his view. In particular, Lee (1996) mentioned that S. alfredii was distributed on Jejudo Island, Korea, while $S$. formosanum was treated as a synonym of this taxon, suggesting that there are no bulbils as a diagnostic character. Previously, some authors (e.g., Liu and Chung, 1977) have considered $S$. formosanum as a synonym of $S$. alfredii. However, Ohba (1984) and Ito et al. (2014) suggested that the two taxa could be treated as separate species based on the analysis of different characters, including erect carpels during the fruiting period, native habitat, and internal transcribed spacer (ITS) sequences. According to $\mathrm{Fu}$ and Ohba (2001), S. formosanum has a branched flower stem from the base, has an erect follicle, inhabits near the coast, while $S$. alfredii usually has a simple flower stem, has an obliquely ascending or horizontal follicle, and inhabits mountains at 2,000?3,000 m above sea level. Based on ITS sequencing, $S$. formosanum was established to be phylogenetically closer to the two Taiwanese endemic species, S. nokoense Yamam. and S. erythrospermum Hayata, compared with any other Sedum taxa, including the Chinese S. alfredii (Ito et al., 2014, 2017). As a result, it may be unreasonable to treat the two taxa as the same species; moreover, considering that $S$. alfredii is distributed in mountains at altitudes of 2,000-3,000 m, it is highly unlikely that this species will be distributed on Jejudo Island. As Kim (1988) pointed out, plants known as S. alfredii in Korea are expected to be $S$. bulbiferum.

As reported by Ito et al. $(2017,2020)$, S. formosanum has been confirmed to be a biennial plant that germinates in the first year, during which it gradually grows and overwinters with leaves, and then in the following year produces flowering stems, blooms, produces fruit, and dies. Some authors (Ohwi, 1984; Fu and Ohba, 2001), however, have described $S$. formosanum as a perennial.

Sedum formosanum is characterized by one alternate leaf at each node of the stem, while $S$. makinoi bears two opposite leaves; $S$. sarmentosum has 3-whorled leaves, while $S$. mexicanum and $S$. kiangnanense are easily distinguishable by having at least 3-5-and 4-5-whorled leaves on their sterile stems, respectively. Furthermore, S. formosanum is easily distinguished from taxa with linear, linear-lanceolate, or terete- oblong leaf blades such as $S$. polytrichoides Hemsl., as they have spatulate or obovate leaf blades with rounded apices. $S$. formosanum is also distinguished from $S$. tosaense, which has leaves with emarginate apices. In addition, S. formosanum differs from most Korean Sedum taxa in that the carpels of fruits grow erect during the fruiting period, whereas the carpels of other taxa are spreading or ascending. Moreover, $S$. formosanum can be distinguished by the fact that the leaves on sterile and flowering stems are similar in shape, whereas $S$. tosaense and S. kiangnanense have dimorphic leaves, and is also conspicuously different from $S$. bulbiferum in that it lacks bulbils on the axils of leaves (Table 1).

The $S$. formosanum plants found growing on Hataedo Island usually reach a height of $45 \mathrm{~cm}$, but can attain heights of $65 \mathrm{~cm}$, albeit rarely, which is taller than the heights previously reported for Sedum taxa in Korea: 10-15 cm (Ohwi, 1984; Fu and Ohba, 2001), 10-25 cm (Ohba, 2001), and 10-30 cm (Ito et al., 2020). Therefore, the size of $S$. formosanum differs substantially from the maximum height $(15 \mathrm{~cm})$ of Sedum indicated in Moon's key to the genera (2018). S. formosanum has been given the local Korean name "Ju-geog-nip-gaet-bi-reum," in reference to the plant's spatula-shaped leaves and its native habitats are beaches.

The following key to the related Korean Sedum taxa has been prepared only for those species with subcircular, obovate, or spatulate leaf blades among taxa with one or two leaves on each node of the stems. Consequently, taxa such as $S$. sarmentosum, S. mexicanum, and S. kiangnanense, which have three or more leaves on each stem node, and taxa such as $S$. uniflorum subsp. oryzifolium (Makino) H. Ohba, S. japonicum Siebold ex Miq., S. polytrichoides, and S. lepidopodum, which are characterized by linear and terete-oblong leaf blades, have not been included in the key.

\section{Key to S. formosanum and related Korean Sedum taxa}

1. Stems typically with bulbils in the leaf axils; leaves generally oblanceolate or rhombic ovate on flowering stems; flowers nearly sterile ……………S. bulbiferum 말똥비름

1. Stems without bulbils in the leaf axils; leaves generally spatulate to obovate, sometimes subcircular on flowering stems; flowers fertile.

2. Stems with distinct segmental nodes; upper leaves somewhat ascending on sterile stems; leaves opposite, rarely verticillate on flowering stems

S. makinoi 둥근잎비름

2. Stems without segmental nodes; upper leaves also 
Table 1. Comparison of several major characteristics of Sedum s.s. in Korea.

\begin{tabular}{|c|c|c|c|c|c|c|c|c|c|}
\hline \multirow{2}{*}{ Taxa } & \multirow{2}{*}{$\begin{array}{l}\text { Phyllotaxy on } \\
\text { sterile stem }\end{array}$} & \multicolumn{3}{|c|}{ Caulescent leaf } & \multirow{2}{*}{ Bulbil } & \multirow{2}{*}{ Follicles } & \multirow{2}{*}{$\begin{array}{l}\text { Articulated node } \\
\text { of stem }\end{array}$} & \multirow{2}{*}{ Life cycle } & \multirow{2}{*}{$\begin{array}{l}\text { Height } \\
(\mathrm{cm})\end{array}$} \\
\hline & & Shape & Apex & Dimorphism $^{a}$ & & & & & \\
\hline S. formosanum & Alternate & $\begin{array}{l}\text { Spatulate, } \\
\text { obovate }\end{array}$ & Rounded & $x$ & $x$ & Erect & $x$ & Biennial & $20-45(-65)$ \\
\hline S. tosaense & Alternate & $\begin{array}{l}\text { Spatulate, } \\
\text { obovate }\end{array}$ & Emarginate & $\bigcirc$ & $x$ & Spreading & $x$ & Perennial & $10-20$ \\
\hline S. bulbiferum & Alternate & Oblanceolate & Obtuse & $x$ & $\bigcirc$ & - & $x$ & Biennial & $5-30$ \\
\hline $\begin{array}{l}\text { S. uniflorum } \\
\text { subsp. oryzifolium }\end{array}$ & Alternate & $\begin{array}{l}\text { Terete- } \\
\text { oblong }\end{array}$ & Rounded & $x$ & $x$ & Spreading & $x$ & Perennial & $5-12$ \\
\hline S. japonicum & Alternate & $\begin{array}{l}\text { Terete- } \\
\text { oblong }\end{array}$ & Rounded & $x$ & $x$ & Ascending & $x$ & Perennial & $5-15$ \\
\hline S. polytrichoides & Alternate & Linear & Acute & $x$ & $x$ & Ascending & $x$ & Perennial & $5-12$ \\
\hline S. lepidopodum & Alternate & Linear & Acute & $x$ & $x$ & Spreading & $x$ & Perennial & $5-15$ \\
\hline S. makinoi & Opposite & Obovate & Rounded & $x$ & $x$ & Ascending & $\bigcirc$ & Perennial & $5-12$ \\
\hline S. sarmentosum & 3-verticillate & $\begin{array}{l}\text { Elliptic, } \\
\text { rhombic }\end{array}$ & Acute obtuse & $x$ & $x$ & Ascending & $x$ & Perennial & $10-15$ \\
\hline S. kiangnanese & $4-5$-verticillate & $\begin{array}{c}\text { Spatulate, } \\
\text { oblanceolate, } \\
\text { linear }\end{array}$ & $\begin{array}{l}\text { Obtuse } \\
\text { acute }\end{array}$ & $\bigcirc$ & $x$ & Spreading & $x$ & Perennial & $10-25$ \\
\hline S. mexicanum & $3-5$-verticillate & $\begin{array}{c}\text { Linear- } \\
\text { lanceolate }\end{array}$ & Obtuse & $x$ & $x$ & - & $x$ & Perennial & $10-25$ \\
\hline
\end{tabular}

${ }^{\mathrm{a}}$ Most taxa of the Korean Sedum have similar leaves on sterile and flowering stems, but some taxa have dimorphic leaves. 
spreading on sterile stems; leaves alternate on flowering stems.

3. Perennial plants with simultaneously flowering and sterile stems; leaves dimorphic, with emarginate apices; carpels spreading during the fruiting period .. S. tosaense 주걱비름

3. Biennial plants with separately flowering and sterile stems; leaves monomorphic, with rounded apices; carpels erect during the fruiting period

\section{S. formosanum 주걱잎갯비름}

ORCID: Seung Se CHOI https://orcid.org/0000-0002-33325544; Jonghwan KIM https://orcid.org/0000-0003-0271-5969; Chul Hwan KIM https://orcid.org/0000-0003-4894-0651

\section{Acknowledgments}

This work was supported by a grant from the 5th National Ecosystem Survey of National Institute of Ecology (NIE), funded by the Ministry of Environment of the Republic of Korea (NIE-A-2020-01).

\section{Conflict of Interest}

The authors declare that there are no conflicts of interest.

\section{Literature Cited}

Brown, N. E. 1885. Sedum formosanum. The Gardeners' Chronicle, New Series 24: 134.

Chung, T. H. 1957. Sedum. In Korean Flora, Vol. II. Herbceous Section. Sinjisa, Seoul. Pp. 284-291. (in Korean)

Forbes, F. B. and W. B. Hemsley. 1887. Sedum. An enumeration all the plants known from China proper, Formosa, Corea, the Luchu archipelago, and the island of Hongkong, together with their distribution and synonymy. Journal of the Linnean Society, Botany 23: 282-288.

Fu, K. J. and H. Ohba. 2001. Crassulaceae. In Flora of China. Vol. 8. Wu, Z. Y. and P. H. Raven (eds.), Science Press, Beijing and Missouri Botanical Garden Press, St. Louis, MO. Pp. 202268.

Ito, T., R. Chen, Q. E. Yang, Y. Saito, M. Yokota and G. Kokubugata. 2014. Taxonomic reexamination of Sedum formosanum (Crassulaceae) in Japan, Taiwan, and the Philippines based on molecular data. Journal of Phytogeography and Taxonomy 62: 1-9.

Ito, T., H. Nakanishi, Y. Chichibu, K. Minoda and G. Kokubugata. 2017. Sedum danjoense (Crassulaceae), a new species of suc- culent plants from the Danjo Islands in Japan. Phytotaxa 309: 23-34.

Ito, T., C.-C. Yu, M. Yokota and G. Kokubugata. 2020. Sedum formosanum subsp. miyakojimense (Crassulaceae), a new subspecies from Miyako-jima Island of the Ryukyu Islands, Japan. PhytoKeys 148: 51-70.

Kim, J. H. 1988. A taxonomic study of the genus Sedum in Korea. $\mathrm{PhD}$ dissertation, Seoul National University, Seoul, Korea. 237 pp. (in Korean)

Lee, T. B. 1980. Illustrated Flora of Korea. Hyangmoonsha Publishing Co., Seoul. Pp. 402-408. (in Korean)

Lee, W. T. 1996. Lineamenta Florae Koreae (I). Academy Publishing Co., Seoul. Pp. 423-436. (in Korean)

Lee, Y. N. 1996. Flora of Korea. Kyo-Hak Publishing Co., Seoul. Pp. 269-274. (in Korean)

Lee, Y. N. 2007. New Flora of Korea I. Kyo-Hak Publishing Co., Seoul. Pp. 482-490. (in Korean)

Liu, T. S. and N. J. Chung. 1977. Crassulaceae. In Flora of Taiwan, Vol. 3. Editorial Committee Flora of Taiwan (ed.), Epoch. Publishing Co., Taipei. Pp. 10-34.

Maximowicz, C. J. 1883. Crassulaceae asiae orientalis et Vicinae centralis in deagnoses plant arum novarum asiaticarum. Bulletin de l'Académie Impériale des Science de St.-Petersbourg, sér. 3 29: 124-291.

Moon, A. R. 2018. A phylogenetic study of the Sedum and Phedimus (Crassulaceae) in Korea. PhD dissertation, Kongju National University, Gongju, Korea. 186 pp. (in Korean)

Moran, R. V. 2009. Crassulaceae. In Flora of North America North of Mexico, Vol. 8. Magnoliophyta: Paeoniaceae to Ericaceae. Flora of North America Editorial Committee (ed.), Oxford University Press, New York. Pp. 147-150.

Nakai, T. 1909. Sedum. In Flora Koreana, Pars Prima. Journal of the College of Science, Imperial University, Tokyo, Japan 26: 226-231.

Nakai, T. 1940. Notulae ad Plantas Asiae Orientalis (XII). Journal of Japanese Botany 16: 1-17.

Nakai, T. 1952. A synoptical sketch of Korean flora. Bulletin of the National Science Museum, Tokyo, Japan 31: 1-152.

Ohba, H. 1984. Notes on the allied species of Sedum alfredii Hance from Taiwan. Journal of Japanese Botany 59: 321-328.

Ohba, H. 2001. Crassulaceae. In Flora of Japan, Vol. 2b. Iwatshuki, K., D. E. Boufford and H. Ohba (eds.), Kadansha, Tokyo. Pp. 10-31.

Ohba, H. 2009. Sedum. In Flora of North America North of Mexico, Vol. 8. Magnoliophyta: Paeoniaceae to Ericaceae. Flora of North America Editorial Committee (ed.), Oxford University Press, New York. Pp. 199-222.

Ohwi, J. 1984. Crassulaceae. In Flora of Japan. Meyer, G. and E. 
H. Walker (eds.), Smithsonian Inst., Washington, D.C. Pp. 493-498.

Palibin, J. W. 1898. Conspectus florae Koreae, Pars Prima. Acta Horti Petropolitani 17: 1-127.

Park, K. R. 2007. Crassulaceae. In The Genera of Vascular Plans of Korea. Flora of Korea Editorial Committee (ed.), Academy Publishing Co., Seoul. Pp. 513-520.

Park, M. K. 1974. Sedum. In Key to the Herbaceous Plants in Korea (Dicotyledoneae). Jeongeumsa, Seoul. Pp. 202-205. (in Korean)

Park, S. H. 2009. New Illustrations and Photographs of Naturalized Plants of Korea. Ilchokak, Seoul. Pp. 144-145. (in Korean)

Park, S.-J. and S.-J. Park. 2005. Sedum makinoi Maxim. (Crassu- laceae): an unrecorded species from Korea. Korean Journal of Plant Taxonomy 35: 193-199. (in Korean)

Song, G.-P., K.-M. Song, H.-J. Hyun, C.-S. Kim and M.-H. Kim. 2004. An unrecorded species in Korean flora: Sedum tosaense Makino (Crassulaceae). Korean Journal of Plant Taxonomy 34: 365-370. (in Korean)

Suh, H.-J., J.-H. Kim, J.-E. Choi, W. Lee, J.-S. Kim and S. Kim. 2020. A new distribution record of Sedum kiangnanense (Crassulaceae) in Korea. Korean Journal of Plant Taxonomy 50: 247-251.

Thiede, J. and U. Eggli. 2007. Crassulaceae. In The Families and Genera of Vascular Plants, Vol. 9. Kubitzki, K. (ed.), Springer, Berlin. Pp. 83-118.

\title{
133년만에 밝혀진 한국산 주걱잎갯비름(돌나물과)의 분류학적 실체 및 분포
}

\author{
최승세 · 김종환 ${ }^{1} \cdot$ 김철환 $^{1 *}$
}

국립생태원 자연환경조사팀, ${ }^{1}$ 성호그린테크

\begin{abstract}
적 요: 한국산 주걱잎갯비름(Sedum formosanum N. E. Br.)은 133년 전에 기록된 후, 이제야 이의 분류학적 실체 및 분포 현황이 밝혀졌다. 이들은 그동안 기준표본 채집지인 타이완을 비롯하여 일본의 남부, 필리핀 북부 섬지역에만 국한하여 분포하는 것으로 알려져 왔다. 그러나 이는 제4차 전국 자연환경조사를 통해 전 라남도 신안군 하태도 및 상태도의 바닷가 바위 틈새에서 생육하는 것으로 확인되었다. 한국산 주걱잎갯비 름은 높이 최대 $65 \mathrm{~cm}$ 에 달하는 2 년생 다육식물로 결실기에 골돌과의 심피가 곧추서는 점에서 속내 대부분 의 식물들과 다르다. 특히, 주걱잎갯비름은 한국산 돌나물속 중, 주걱비름과 비슷하지만 엽신이 단일형으로 엽선이 원두이며, 꽃 피는 줄기와 꽃이 없는 줄기를 따로따로 갖는 점에서 구별된다. 주걱잎갯비름에 대한 기재, 근연종과 차이점, 검색표 및 사진 등을 수록하였다.
\end{abstract}

주요어: 분류학적 실체, 주걱잎갯비름, 돌나물속, 돌나물과, 섬 지역 